\title{
Metamafic Rocks of the Tana Belt, Kola Peninsula: Isotopic Age and PT Conditions
}

\author{
L. L. Perchuk ${ }^{a}$, J. D. Kramers ${ }^{b}$, V. O. Yapaskurt ${ }^{a}$, and A. V. Krotov ${ }^{a}$ \\ Presented by Academician A.A. Marakushev May 30, 2005
}

Received September 27, 2005

DOI: $10.1134 / \mathrm{S} 1028334 \mathrm{X} 06040258$

According to [1, 2], mica schists of the Korva Tundra Group $(\sim 1.91 \mathrm{Ga}[3,4])$ of the Tana Belt were buried at the middle crustal level and later exhumed simultaneously with granulites of the Lapland Complex ( 1.91 Ga [5]). The Kandalaksha Group (KG) is composed of higher-temperature rocks $[1,6]$, but their geodynamic evolution is similar to that of the Korva Tundra Group [2]. Since the KG rocks have not been previously dated in this area, their synchronous metamorphism with Lapland granulites has not been proved. To solve this problem, metamorphic $P T$ conditions and $\mathrm{U}_{-}$ $\mathrm{Pb}$ zircon ages were determined for two KG samples taken in the Pados-Yavr interfluve. The results are presented in this work.

The hypersthene-biotite plagiogneiss (sample Pal-9) is a fine- to medium-grained light gray blastomylonitic rock with biotite schistosity and vague quartz-plagioclase gneissosity. This appearance is related to uneven distribution of melanocratic and leucocratic minerals. The schistosity defined by the preferred orientation of biotite coincides with banding. The texture is lepidogranoblastic. Major rock-forming minerals (Qtz and $\mathrm{Pl}$ ) in equal proportions compose from 50 to $80 \%$ of rock. The Bt content varies within $30-40 \%$ in the melanocratic portions and within 5-10\% in the leucocratic portions. Orthopyroxene (10-15\%) is mainly accumulated in the melanocratic bands and lenses. Opx occurs as an accessory mineral in other parts of the rock. How-

\footnotetext{
Abbreviations: (Ap) apatite, (Bt) biotite, (Cpx) clinopyroxene, (Grt) garnet, $(\mathrm{Hbl})$ hornblende, $(\mathrm{Opx})$ orthopyroxene, $(\mathrm{Qtz})$ quartz, $(\mathrm{Pl})$ plagioclase, $(\mathrm{Sph})$ sphene, $(\mathrm{Zrn})$ zircon, $(T)$ temperature, $(P)$ pressure, $X_{\mathrm{Mg}}=\mathrm{Mg} /(\mathrm{Mg}+\mathrm{Fe}), X_{\mathrm{Ca}}^{\mathrm{Grt}}=\mathrm{Ca} /(\mathrm{Ca}+\mathrm{Mg}+\mathrm{Fe}+\mathrm{Mn})$.
}

\footnotetext{
${ }^{a}$ Geological Faculty, Moscow State University, Leninskie gory, Moscow, 119992 Russia; e-mail:llp@geol.msu.ru

${ }^{\mathrm{b}}$ Institute of Mineralogy and Petrography, University of Bern, Erlachstr 9a, CH-3012 Bern, Switzerland; e-mail:kramers@mpi.unibe.ch
}

ever, both forms of Opx lack mineral inclusions. Some large Opx grains are rimmed by Bt flakes. Secondary minerals are nearly absent.

The garnet-clinopyroxene crystalline schist (sample Lap-34) is a medium-grained dark green rock with a lenticular-banded structure and porphyritic heterogranoblastic texture. The rock is similar in appearance to eclogite. However, the Cpx composition does not correspond to omphacite. Its structure is defined by the uneven distribution of Grt and leucocratic minerals. $\mathrm{Cpx}$ is the major rock-forming mineral (up to 90\%). Garnet accounts for $\sim 10 \%$. Qtz and Pl account for no more than 1-2\%. Locally, Cpx decreases and gives way to amphibole (up to $10-15 \%$ ). Ilmenite, rutile, and zircon are accessory minerals. The Grt porphyroblasts are unevenly distributed as intermittent chains, which are aligned with Pl-rich lenses and bands. Scarce inclusions in the Grt are typically small (up to $1 \mathrm{~mm}$ ) Cpx, which occasionally form chains marking the surface of intergrown garnet grains in a porphyroblast. The representative analyses of equilibrium $\mathrm{Cpx}$, Grt, and Pl are shown in Table 1. Occasionally, Grt contains Pl inclusions $(\sim 0.5 \mathrm{~mm})$. In the Hbl-rich domains, Grt contains $\mathrm{Hbl}$ inclusions that are compositionally similar to the groundmass hornblende. Hornblende is typically absent or developed as thin $(10-15 \mu \mathrm{m})$ interrupted rims around clinopyroxene. Only locally, $\mathrm{Hbl}$ occurs as small xenomorphic grains up to $0.2 \mathrm{~mm}$ across. Elongated grains with convoluted boundaries are less common. Xenomorphic Pl grains (up to $0.2-0.3 \mathrm{~mm}$ across) more often occur as a rim in the Cpx-rich granoblastic matrix. The larger (up to $0.5 \mathrm{~mm}$ ) equant Pl grains form lenticular aggregates from $1 \times 10$ to $1 \times 15 \mathrm{~mm}$ in size. The garnet has a constant grossular mole fraction $\left.\left(X_{\mathrm{Ca}}^{\mathrm{Grt}}\right)=0.28\right)$, while the $\mathrm{Mg}$ index, $X_{\mathrm{Mg}}=\mathrm{Mg} /(\mathrm{Mg}+\mathrm{Fe})$ decreases by $10 \mathrm{~mol} \%$ from the core to the rims. Cpx lacks inclusions and occurs as two morphological types. The predominant type is represented by xenomorphic subequant or slightly elongated polygonal grains up to $0.5-0.7 \mu \mathrm{m}$ across. The second type is represented by large (up to $5 \times 4 \mathrm{~mm}$ across) weakly 
Table 1. Compositions of minerals from the Pl-bearing garnet-clinopyroxene schist (sample Lap-34), Tana Belt, southern contact of the Lapland granulite belt, the Kola Peninsula

\begin{tabular}{|c|c|c|c|c|c|c|c|c|}
\hline \multirow{4}{*}{ Component } & \multicolumn{2}{|c|}{ Garnet } & \multicolumn{5}{|c|}{ Clinopyroxene } & \multirow{4}{*}{$\begin{array}{l}\text { Plagioclase } \\
\begin{array}{c}\text { contact with } \\
\text { Cpx and Grt } \\
\text { of the matrix }\end{array} \\
0871\end{array}$} \\
\hline & \multirow{3}{*}{$\begin{array}{l}\text { core } \\
0895\end{array}$} & \multirow{3}{*}{$\begin{array}{c}\begin{array}{c}\text { contact with } \\
\text { matrix Cpx }\end{array} \\
0872\end{array}$} & \multicolumn{3}{|c|}{ Matrix grains } & \multicolumn{2}{|c|}{ Inclusions in Grt } & \\
\hline & & & \multirow{2}{*}{$\begin{array}{l}\text { core } \\
0892\end{array}$} & \multicolumn{2}{|c|}{ contact with Grt } & \multirow{2}{*}{$\begin{array}{l}\text { core } \\
0876\end{array}$} & \multirow{2}{*}{$\frac{\text { rim }}{0875}$} & \\
\hline & & & & 0881 & 0891 & & & \\
\hline $\mathrm{SiO}_{2}$ & 40.11 & 39.25 & 49.99 & 52.33 & 50.99 & 50.25 & 50.50 & 50.21 \\
\hline $\mathrm{TiO}_{2}$ & 0.10 & 0.00 & 0.28 & 0.22 & 0.43 & 0.56 & 0.34 & 0.00 \\
\hline $\mathrm{Al}_{2} \mathrm{O}_{3}$ & 21.86 & 22.04 & 7.42 & 4.24 & 6.29 & 7.23 & 6.20 & 31.91 \\
\hline $\mathrm{Cr}_{2} \mathrm{O}_{3}$ & 0.33 & 0.04 & 0.28 & 0.11 & 0.17 & 0.26 & 0.38 & 0.00 \\
\hline $\mathrm{FeO}$ & 18.63 & 20.96 & 6.65 & 5.50 & 6.52 & 6.84 & 6.60 & 0.14 \\
\hline $\mathrm{MnO}$ & 0.46 & 0.66 & 0.08 & 0.00 & 0.00 & 0.10 & 0.00 & 0.00 \\
\hline $\mathrm{MgO}$ & 8.92 & 6.76 & 12.10 & 13.63 & 12.56 & 11.87 & 12.84 & 0.00 \\
\hline $\mathrm{CaO}$ & 9.60 & 10.16 & 21.68 & 22.87 & 22.59 & 21.89 & 22.18 & 14.70 \\
\hline $\mathrm{Na}_{2} \mathrm{O}$ & 0.00 & 0.08 & 1.39 & 0.83 & 0.42 & 0.84 & 0.91 & 2.95 \\
\hline $\mathrm{K}_{2} \mathrm{O}$ & 0.00 & 0.01 & 0.05 & 0.00 & 0.03 & 0.00 & 0.06 & 0.08 \\
\hline \multicolumn{9}{|c|}{ Crystallochemical formula } \\
\hline $\mathrm{Si}$ & 3.02 & 3.01 & 1.83 & 1.92 & 1.88 & 1.85 & 1.85 & 2.29 \\
\hline $\mathrm{Al}$ & 1.94 & 1.99 & 0.32 & 0.18 & 0.27 & 0.31 & 0.27 & \\
\hline $\mathrm{Al}^{\mathrm{IV}}$ & 0.00 & 0.00 & 0.17 & 0.08 & 0.12 & 0.15 & 0.15 & 1.71 \\
\hline $\mathrm{Al}^{\mathrm{VI}}$ & 1.94 & 1.99 & 0.15 & 0.11 & 0.15 & 0.17 & 0.12 & \\
\hline $\mathrm{Cr}$ & 0.02 & 0.00 & 0.00 & 0.00 & 0.00 & 0.00 & 0.01 & 0.00 \\
\hline $\mathrm{Ti}$ & 0.01 & 0.00 & 0.01 & 0.01 & 0.01 & 0.02 & 0.01 & 0.00 \\
\hline $\mathrm{Fe}^{3+}$ & 0.03 & 0.01 & 0.11 & 0.03 & 0.00 & 0.04 & 0.08 & \multirow{2}{*}{0.01} \\
\hline $\mathrm{Fe}^{2+}$ & 1.14 & 1.33 & 0.10 & 0.14 & 0.20 & 0.18 & 0.12 & \\
\hline $\mathrm{Mn}$ & 0.03 & 0.04 & 0.00 & 0.00 & 0.00 & 0.00 & 0.00 & 0.00 \\
\hline $\mathrm{Mg}$ & 1.00 & 0.77 & 0.66 & 0.75 & 0.69 & 0.65 & 0.70 & 0.00 \\
\hline $\mathrm{Ca}$ & 0.78 & 0.83 & 0.85 & 0.90 & 0.89 & 0.87 & 0.87 & 0.72 \\
\hline $\mathrm{Na}$ & 0.00 & 0.01 & 0.10 & 0.06 & 0.03 & 0.06 & 0.06 & 0.26 \\
\hline $\mathrm{K}$ & 0.00 & 0.00 & 0.00 & 0.00 & 0.00 & 0.00 & 0.00 & 0.00 \\
\hline $\mathrm{O}$ & 12.00 & 12.00 & 6.00 & 6.00 & 6.00 & 6.00 & 6.00 & 8.00 \\
\hline$X_{\mathrm{Mg}}$ & 0.46 & 0.36 & 0.87 & 0.84 & 0.77 & 0.79 & 0.85 & - \\
\hline$X_{\mathrm{Ca}}$ & 0.26 & 0.28 & - & - & - & - & - & 0.73 \\
\hline
\end{tabular}

resorbed grains. The mineral mainly consists of diopside (63-72 mol \%) and hedenbergite (10-20 mol \%) end members. Aegirine accounts for up to $10 \mathrm{~mol} \%$, while $\mathrm{Ca}$ - and $\mathrm{Mg}$-Tschermak molecules account for up to 12 and $6 \mathrm{~mol} \%$, respectively. The jadeite content is no more than 2-3 mol \%. Variations of $X_{\mathrm{Mg}}^{\mathrm{Cpx}}$ in different parts of the Cpx grains are as much as $10 \mathrm{~mol} \%$. Compositional variations of individual $\mathrm{Cpx}$ and $\mathrm{Grt}$ are similar. However, in Cpx of the matrix, $X_{\mathrm{Mg}}^{\mathrm{Cpx}}$ decreases toward the rim, while the $\mathrm{Al}$ mole fraction remains constant. Cpx inclusions in Grt show an opposite trend. At the contact with Grt, the diopside content $N_{\mathrm{Mg}}$ is typical of matrix grains, while the $\mathrm{Al}$ content insignificantly decreases. Cpx in the matrix and Grt-hosted inclusions are similar in $\mathrm{Al}$ content $(0.18-0.33$ f.u. based on 6 oxygen atoms), but they differ in the Na content. In particular, Cpx in the matrix has the highest $\mathrm{Al}$ content in the core ( 0.1 f.u. based on 6 oxygen atoms), while Na content decreases in the rims up to $0.07-0.03$ f.u. The $\mathrm{Na}$ content in Cpx from Grt is $0.06 \mathrm{f}$.u. In the Cpx from the matrix, Na shows a positive correlation with $\mathrm{Fe}^{3+}$ (aegirine), while $\mathrm{Al}$ positively correlates with $\mathrm{Ca}(\mathrm{Ca}-\mathrm{Tscher}-$ mak molecule). Aegirine also shows positive correlation with the Ca-Tschermak molecule. Plagioclase corresponds to $\mathrm{An}_{73} \mathrm{Ab}_{27}$ with no $\mathrm{K}$ and anthiperthite. The representative compositions of the minerals are shown in Table 1. 


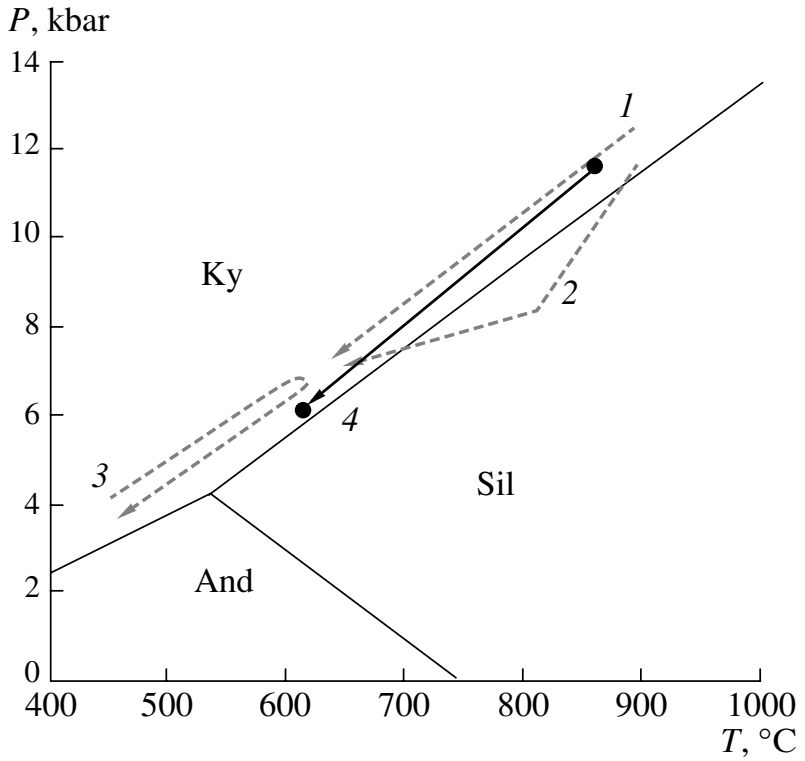

Fig. 1. $P T$ path of the metamorphic evolution of the granulites of the Lapland Complex ( 1 and 2 ) and mica schists of the Tana Belt (3). 1 and 2 are taken from $[2,6,10] ; 3$, from [1], and 4, our data.

Mineral zoning in sample Lap-34 (Table 1) was used to determine the minimum and maximum peak $P T$ conditions of local equilibrium. The temperatures were calculated using a Grt-Cpx thermometer [8]. Since the jadeite component in Cpx is insignificant, the pressure was calculated from the Cpx-Grt-Pl-Qtz barometer according to [9]. The peak $P T$ metamorphic conditions were determined from the compositions of mineral cores, while the minimum $P T$ parameters were obtained from compositions of the adjacent Grt and Cpx, because plagioclase occurs both in the matrix and as inclusions in garnets. Since there are no direct contacts of Grt and Cpx with plagioclase and quartz, the pressure was calculated only for the local rock portions. The calculated maximum values $T=865 \pm 30^{\circ} \mathrm{C}$ and $P=11.5 \pm 1$ kbar correspond to the metamorphic peak [10], while the minimum values $T=615 \pm 20^{\circ} \mathrm{C}$ and $P=6.3 \pm 1$ kbar correspond to the emplacement of the rock complex at the middle crustal level. It is noteworthy that, like the Lapland Granulite Complex (LGC), the studied assemblage does not yield lower $P T$ exhumation parameters. Figure 1 demonstrates the $P T$ path for the studied sample (path 4). The path coincides with the exhumation path of the metamafic rocks of LGC

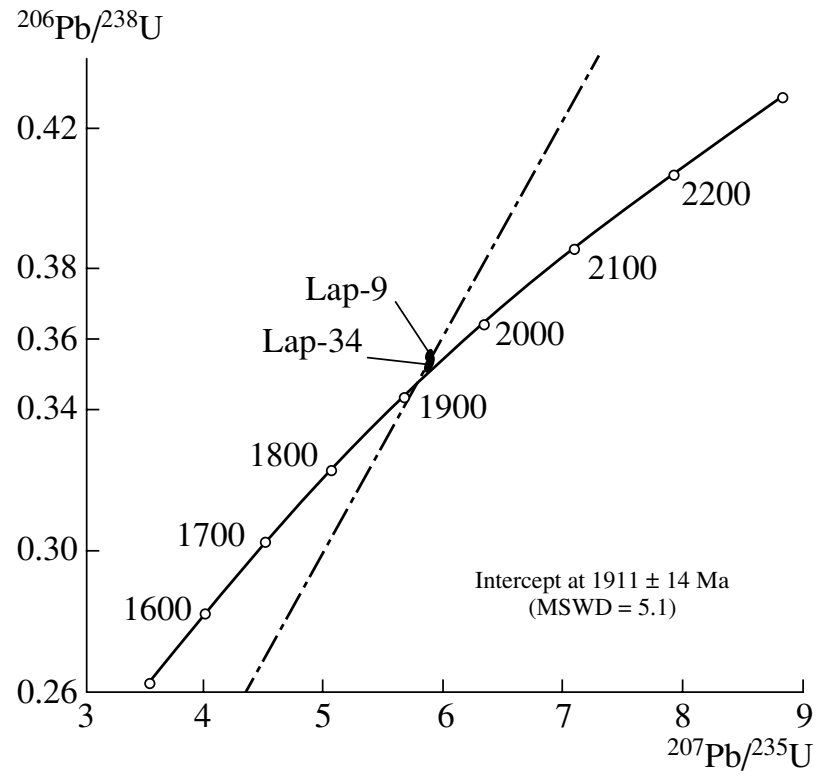

Fig. 2. U-Pb concordia diagram for the studied samples (see Table 2).

[10]. The calculated $P-T$ values are atypical of the rocks of the Tana Belt, i.e., garnet amphibolites of the Kandalaksha Group (Fig. 1, path 2) and associated mica schists of the Korva Tundra Group (path 3), but they completely correspond to the formation conditions of the granulites of the Lapland Complex (path 1). Hence, the isotope age of the studied rocks should match the age of the Lapland granulites.

To solve this problem, zircons were separated from both samples. Their ages were determined on a mass spectrometer using standard techniques $[5,11]$. The results are shown in Table 2 and Fig. 2. Obtained data fall within the range typical of the main evolutionary stages of the LGC.

The obtained metamorphic parameters and isotope data indicate that the studied samples were formed and exhumed simultaneously with the LGC rocks. This also implies that the garnet amphibolites, typically ascribed to the Kandalaksha Group of the Tana Belt, represent the near-contact zone of the LGC, which was partially affected by schistosity and blastesis at the middle crustal level. At the immediate contact with the host rocks, they form a melange and ascend as relatively rare blocks and boudins among two-mica schists. According to this scenario, the southern boundary of the LGC

Table 2. U-Pb age of zircons from metabasalts Lap-9 and Lap-34 (Fig. 1) from the Tana Belt

\begin{tabular}{c|c|c|c|c|c|c|c|c|c|c|c|c}
\hline $\begin{array}{c}\text { Sample } \\
\text { no. }\end{array}$ & $\begin{array}{c}\text { Weight } \\
(\mathrm{mg})\end{array}$ & $\frac{{ }^{206} \mathrm{~Pb}}{204}$ & $\frac{{ }^{208} \mathrm{~Pb}}{{ }^{206} \mathrm{~Pb}}$ & $\begin{array}{c}\mathrm{U}, \\
\mathrm{ppm}\end{array}$ & $\begin{array}{c}\mathrm{Pb}^{*}, \\
\mathrm{ppm}\end{array}$ & $\begin{array}{c}\mathrm{Pb}_{\text {total }}, \\
\mathrm{ppm}\end{array}$ & $\begin{array}{c}{ }^{207} \mathrm{~Pb} \\
{ }^{206} \mathrm{~Pb}\end{array}$ & $\pm 2 s, \%$ & $\frac{{ }^{207} \mathrm{~Pb}}{{ }^{235} \mathrm{U}}$ & $\pm 2 s, \%$ & $\frac{{ }^{206} \mathrm{~Pb}}{{ }^{238} \mathrm{U}}$ & $\pm 2 s, \%$ \\
\hline LAP-34 & 2.50 & 2061.9 & 0.0612 & 45.92 & 16.41 & 16.83 & 0.1174 & 0.2961 & 5.70315 & 0.5561 & 0.352279 & 0.4466 \\
LAP-09 & 2.18 & 2172 & 0.3558 & 54.25 & 24.43 & 24.91 & 0.1169 & 0.1859 & 5.71945 & 0.3019 & 0.354815 & 0.2203 \\
\hline
\end{tabular}


should be placed along the northern boundary of the Korva Tundra Group rather than along the Yavr River, as was proposed in [1]. This interpretation solves the problem of determining the exact geological position of two-mica schists and is consistent with the model of their evolution at the contact with LGC [1]. Consequently, garnet amphibolites of the Kandalaksha Group were strongly deformed by the upward displacement of the southern contact of the LGC at $\sim 12^{\circ}$. However, they were not overprinted by low-grade metamorphism. If this conclusion is valid for other parts of the southern contact of the LGC with the Karelian Craton, it will be evident that the Tana Belt evolved not only as a tectonic boundary between the Karelian Craton and the Lapland granulite complex, but also spanned both these large geological structures [12].

\section{ACKNOWLEDGMENTS}

This work was supported by the Russian Foundation for Basic Research (project no. 05-05-64196) and the Foundation of the President of the Russian Federation for the Support of the Leading Scientific Schools (project no. 1645. 05.2003.).

\section{REFERENCES}

1. L. L. Perchuk and A. V. Krotov, Petrology 6, 149 (1998).
2. L. L. Perchuk, T. V. Gerya, D. D. van Reenen, et al., Mineral. Petrol. 69, 109 (2000).

3. K. Merilainen, Geol. Surv. Finl. Bull. 281 (1976).

4. O. I. Volodichev, The Belomorian Complex of Karelia: Geology and Petrology (Nauka, Leningrad, 1990) [in Russian].

5. E. V. Bibikova, V. F. Mel'nikov, and K. Kh. Avakyan, Petrologiya 1, 215 (1993).

6. M. V. Mints, V. N. Glaznev, A. N. Konilov, et al., Early Precambrian of the Northeastern Baltic Shield: Paleogeodynamics, Structure, and Evolution of the Continental Crust (Nauchnyi Mir, Moscow, 1996) [in Russian].

7. T. V. Gerya and L. L. Perchuk, in Proceedings of IMA 15th General Meeting, Beijing, China, 1990 (Beijing, 1990), Vol. 2, p. 1010.

8. Y. Ai, Contrib. Mineral. Petrol. 115, 467 (1994).

9. T. C. McCarthy and A. E. Patino Douce, J. Metamorph. Geol. 16, 671 (1998).

10. V. I. Fonarev, A. A. Grafchikov, and A. A. Konilov, in Experimental Problems of Geology (Nauka, Moscow, 1994), pp. 323-355 [in Russian].

11. K. Kreissig, L. Holzer, R. Frei, et al., Precambrian Res. 109, 145 (2001).

12. L. L. Perchuk and T. V. Gerya, in Experimental Mineralogy at the Turn of Centuries (Nauka, Moscow, 2004), pp. 137-157 [in Russian]. 